\title{
THE SUI GENERIS NATURE OF THE COMPREHENSIVE ECONOMIC AND TRADE AGREEMENT BETWEEN CANADA AND THE EUROPEAN UNION
}

\author{
Marija Fileva \\ Faculty of Law "Iustinianus Primus" - Skopje, North Macedonia \\ ORCID iD: https://orcid.org/0000-0001-5035-6580 \\ marija_fileva@hotmail.com
}

\begin{abstract}
The Comprehensive Economic and Trade Agreement between Canada and the European Union (CETA) due the contracting parties include a large number of involved countries, which fact creates an ambiguous possibility of various implications in the worldwide business practice considering the different national legal systems. In my paper I am using a deductive approach to the relationship between the theory and the research with an emphasis on the two research questions: Why the ISDS (Investor State Dispute Settlement) from CETA sparked the greatest attention?, and What is causing the legal discrepancy between the CETA's provisions on hard copy and the possible implementation in business practice?. My paper is focused on the implications from the CETA's concluding in the business practice, taking into consideration that CETA is a combination of strengths and weaknesses, opportunities and possible threats.
\end{abstract}

Keywords: Comprehensive Economic and Trade Agreement; CETA; Sui Generis; International Trade Law; European Union; ISDS; Investor State Dispute Settlement

\section{INTRODUCTION}

The Comprehensive Economic and Trade Agreement (CETA) with Canada is one of the most ambitious and progressive trade agreements the EU has ever concluded. It offers companies in both the EU and Canada new opportunities for transatlantic trade and investment, giving EU exporters - large and small - much improved access to one of the world's most developed markets (European Commission 2017). 
CETA analyzed through the prism of the contracting parties, it is presented to the public as an Agreement from which everyone will have an enormous benefit considering the scope of the Agreement for example like abolition of customs duties, open and nondiscriminatory access to the market, better mobility for employees and protected large variety of geographical indications for high-quality food products. But, besides the previous mention enormous possibilities and the significantly more like the developing of good practice, supporting the investment in healthy environment, stimulation of economic stability and social development, CETA is an Agreement that has become recognized for the criticism from the general public as a negative consequence due the negotiation process that was kept in secret for a long period of time. The fact that the negotiations for CETA were kept in secret for a very long time created the deep space for possible disagreements and conflict between the entities, while at the same time the potential risk of unsuccessful coordination in the field of international trade policy is within the bounds of possibility to happen.

Without doubt the conclusion of CETA sparked significant public reactions and in spite of everything that was bring into attention like the environmental protection, sustainable development, lower prices for consumers while upholding the EU's high standards such as those on food and product safety, the ISDS (Investor State Dispute Settlement) was on the top of the discussions. The new investment court system presented as a court system which will offer certainty and predictability to investors, while protecting the public interest didn't 'safeguard' the contracting parties from the public protests, petition and campaigns leaded on the behalf of many organizations, trade unions and social movements that were organized across the Europe. During the course of those events the public delivered a message to the contracting parties that they are rejecting the ISDS as a system which is on the side of the corporations and demand new set of global regulations and principles for the multinational corporations.

Giving consideration to the previous mention, while analyzing CETA's Investment chapter, I research the possibility of double interpretation: on the one hand is the benefit and justification for achieving the purpose for which is concluded this chapter in CETA, but on the other hand it can also be interpreted as contradiction that resulted with dissatisfaction and confusion due the formulation of the Agreement's provisions. With my research I would like to make a contribution to the analysis of a sui generis agreement such as CETA and to observe the alternatives that are pro et contra the formulation of the specific provisions in this Agreement. 


\section{THE ECONOMIC RELATIONSHIP AND THE NEGOTIATION PROCESS OF THE COMPREHENSIVE ECONOMIC AND TRADE AGREEMENT BETWEEN CANADA AND THE EUROPEAN UNION (CETA)}

Thanks to CETA, Canadian and EU businesses will now compete on a truly level playing-field. That will create a host of new opportunities on the Canadian market for EU companies, especially smaller ones with up to 250 employees, which together account for 99\% of all companies in Europe. In fact, with CETA Canada has agreed to give EU companies better conditions for doing business than it gives to companies from other countries (European Commission 2017). CETA from the contracting parties is described as one of a kind agreement that will set the standards for concluding all the future trade agreements because it has unique structure. The chances for progress of the small and medium enterprises will come into sight in view of the fact that they are very often in unfavorable position on the market where the rules of the 'game' are set by the gigantic companies. Another positive implication in the business practice is the elimination of fees, so the export is expected to grow and gradually increase as a positive implication from the concluding of this Agreement. CETA includes modern rules on investment that preserve the right of governments to regulate in the public interest including when such regulations affect a foreign investment, while ensuring a high level of protection for investments and providing for fair and transparent dispute resolution. CETA will not result in foreign investors being treated more favorably than domestic investors. CETA does not privilege recourse to the investment court system set up by the Agreement. Investors may choose instead to pursue available recourse in domestic courts (Official Journal of the European Union 2017).

In the Investment chapter from CETA is incorporated innovative aspect in the content of the provisions that resulted with intriguing repercussions in the field of international trade and investment law. But, not so captivating for everyone and modern as it is presented in the Joint Interpretative Instrument on CETA mention before taking into consideration the petition 'Rights for People, Rules for Corporations - Stop ISDS!', as listed on its website in the blog by Alex Scrivener on July 16, 2019 named CETA - It's not too late to stop it: "So here we are again. Trying to stop the EU-Canada trade and investment deal CETA. We've been fighting this one for a while. CETA was first proposed back in 2009. It was later dubbed the "little sibling" of the more famous EU-US deal TTIP. It is pretty much just as bad as TTIP though as it also includes ISDS - the obscure system of 'corporate courts' that allows multinationals to sue countries for standing up for their citizens" (Scrivener 2019).

This petition has a characteristic focus precisely on stopping the ISDS, called 'Rights for People, Rules for Corporations - Stop ISDS!' as listed on its website it was launched last year across the member states of the European Union on the behalf of their whole alliance of over 200 organizations, trade unions and social movements and they are fighting for more rights for the citizens in comparison with those of the corporation's (Alliance Rights for People, Rules for Corporations - Stop ISDS! 2020). One of the biggest challenges concerning 
this initiative is stopping ISDS and according to the leaders of the initiative, corporations without the constitution of the ISDS have already tremendous financial power and there is no need for establishing a separate system that will provide more rights on the behalf of the corporations. Furthermore, this movement has the tendency to give importance to the fact that corporations increasingly have an expansion of their power and due to this reason, reducing the rights of corporations and achieving a balance between their financial benefits and obligations is more than inevitable needed.

Under CETA, foreign investors still receive extraordinary legal rights to sue governments for measures that may negatively affect their investments. These protections, which are not available to domestic investors or ordinary citizens, would expose taxpayers to huge financial liabilities and threaten to chill public policy. Although the text mentions a socalled right to regulate, the clause is a guideline and does not adequately protect public interest regulation (Canadian Centre for Policy Alternatives 2016).

Giving consideration to the initiative for stopping ISDS, the commitment for building a world of solidarity and the aspiration for dispersion of the corporations' power, while the leaders of this campaign consider the ISDS as a global threat that concerns democracy, rule of law, environmental protection, human rights, health, public services, consumers and labor rights is reasonable. Why reasonable? In view of the fact that the aversion about ISDS'S constitution is a result referring to the implications from the superior position coming out of the corporations in the business practice when actually it is necessary a limitation of their benefits and remodeling of the corporate privileges. It's not difficult to be aware why there were a lot of public gatherings for stopping the ISDS, in order to have more responsibilities on the behalf of the corporations and rules that are effectively implemented. The dissatisfaction against the ISDS is reasonable because from one point of view we have the presentation of CETA as an agreement that will provide the greatest condition for the general public, while in the same Agreement we have the ISDS which is defocusing the attention from the importance of the ordinary citizens and consideration of their interests.

The inclusion of a set of investment protection standards in CETA and a dispute resolution procedure which caters exclusively to foreign investors - and which are not available to domestic investors - clearly violates the mandate that foreign investors should not benefit from greater rights than domestic investors (International Centre for Trade Union Rights 2016).

\section{THE FORM, SCOPE AND THE PROVISIONS OF THE COMPREHENSIVE ECONOMIC AND TRADE AGREMEENT BETWEEN CANADA AND THE EUROPEAN UNION (CETA)}

A trade liberalization agreement between two or more states can be a complex process that may take a number of years to complete, especially if the agreement covers a wide range of issues, as is the case with the discussions aimed at reaching a CETA between Canada and the EU (House of Commons Canada 2012). Considering that CETA contains 
many provision such as national treatment and market access for goods, trade remedies, investment, mutual recognition of professional qualifications, international maritime transport services, telecommunications, electronic commerce, competition policy, intellectual property, trade and sustainable development, transparency and dispute settlement and etc. (Canadian Government and the European Commission. CETA 2016), made this Agreement to have an enormous scope that is confusing for the wider public.

The weaknesses that are arising from the concluding of CETA the contracting parties tried to keep under wraps by launching a marketing campaign with intention to produce a positive effect on the entire procedure, representing CETA as a chance that has not been available to consumers, investors and all involved in the business community till the concluding of this Agreement. The contracting parties set up the ambitious aims in CETA as helping the companies to sell more services with the abolition of customs duties, promoting high-quality investment, new possibilities for selection and new opportunities for observing products or services for the consumers or the potential consumers. Buyers will benefit on the grounds that they will have a new open market and they will have new alternatives that previously were not available to them. But, the open market for goods and services will not mean that standards will be reduced or changed in a negative connotation, because standards relating to health, safety, customer safety or the healthy environment will have to be respected, without any exception and stay uphold high.

One of the biggest issues arising from the concluding of CETA is the creating and the establishment of the Tribunal. The CETA Joint Committee shall, upon the entry into force of this Agreement, appoint fifteen Members of the Tribunal (CETA, Article 8.27.2 Constitution of the Tribunal, 59). The Members of the Tribunal shall possess the qualifications required in their respective countries for appointment to judicial office, or be jurists of recognized competence. They shall have demonstrated expertise in public international law. It is desirable that they have expertise in particular, in international investment law, in international trade law and the resolution of disputes arising under international investment or international trade agreements (CETA, Article 8.27.4 Constitution of the Tribunal, 59). The Tribunal shall hear cases in divisions consisting of three Members of the Tribunal, of whom one shall be a national of a Member State of the European Union, one a national of Canada and one a national of a third country. The division shall be chaired by the Member of the Tribunal who is a national of a third country (CETA, Article 8.27.6 Constitution of the Tribunal, 60).

Intriguing part from the Agreement is the one that is dedicated to the ethics of the appointed members of the Tribunal. It is stated that the Members of the Tribunal shall be independent. They shall not be affiliated with any government. They shall not take instructions from any organization, or government with regard to matters related to the dispute. They shall not participate in the consideration of any disputes that would create a direct or indirect conflict of interest (CETA, Article 8.30.1 Ethics, 63).

But what brings into question the bias, objectivity and ethics in this situation when is in question the establishment of the Tribunal in CETA? The biggest concern that is always in the 
center of public debates is that the ISDS creates the space for foreign investors to make direct or indirect pressure on the Governments to meet their aspirations and targeted goals, imposing the fear in the public about the possibility of initiating billion worth lawsuits.

CETA establishes strict rules of ethical behavior for the Members of the Tribunal which guarantee their full independence and impartiality. Situations where a Member of the Tribunal can act as a counsel or an expert in pending or new investment disputes are prohibited. Further, CETA has a binding code of conduct for the members of the Tribunal. The code is based on the ethical rules of the International Bar Association, subject to further revision. It prevents conflicts of interest. In case a member of the Tribunal is found not to comply with the code, he/she will be replaced. That decision is taken by an independent outside party - the President of the International Court of Justice and not by the remaining Members of the division of the Tribunal hearing the case as is often the case in existing agreements (European Commission 2016).

The argumentation in the above mention statement from the European Commission is insufficient and creates the deep space for another concern on the behalf of the general public. The qualifications of the Tribunal members are only provided with the non-obligatory words SHALL and DESIRABLE, which in no case is a guarantee that the members of the Tribunal are going to fulfill their obligations with independence and objectivity in solving the dispute, for which they have been selected. In the previously mention provisions from CETA, it's easy for perceiving that there are countless qualifications and rules that should be fulfilled by the selected members that are going to be part of the Tribunal, while nowhere exactly is specified in which way they are going to prove the preferred competencies.

\section{THE COMPREHENSIVE ECONOMIC AND TRADE AGREEMENT BETWEEN CANADA AND THE EUROPEAN UNION (CETA) VERSUS THE BUSINESS PRACTICE}

With the signing of CETA, questions arise concerning the magnitude of the benefits and impacts, as well as how they will be distributed. Liberalizing trade is intended to bring benefits through greater specialization (based on comparative advantage). This is the projected effect on the overall economy, but the impact on sectors could be uneven (Office of Parliamentary Budget Officer, Canada 2017).

Regardless the benefits that were emphasized by the contracting parties, it is not really straightforward how CETA is going to enhance the lives of the citizens of EU member states and Canada. Is that going to be achieved with the new range of possible alternatives which will not lower the quality and the same will stay on a level that fulfills all the quality standards of the products? Perhaps, it is about the opportunity of the workers' mobility, helping them to be more competitive in the labor market, to find better jobs, better possibilities and the transit of the companies? Or maybe, it is about the claiming from the contracting parties that CETA will allow the companies in European Union member states to 
invest outside the borders of the European Union under such enormous benefits with elimination of the barriers for investment and the equal and fair treatment for the investors?

CETA's chapter 8 , section $F$ on the "resolution of investment disputes between investors and states" grants corporations the right to bypass national courts and directly file highly enforceable multi-billion euro compensation claims against states in international tribunals. But the tribunals are not judicially independent. Rather, they have a built-in, proinvestor bias (Corporate Europe Observatory 2016).

Having in mind the above mention initiative 'Rights for People, Rules for Corporations - Stop ISDS!', the free access to the market for goods and services and circulation of movement does not always mean stimulation of opening new jobs, but on the contrary it can mean loss of existing, inequality in the distribution of the labor market and fragmentation in the concentrations of certain work positions. If the rights of the workers are protected by CETA, there is no reason why the workers would sign the petition and went to public protest to prevent the concluding of the agreement. One business society undoubtedly can't have a sustainable development without the arrangement of meaningful investment strategies with accredited foreign investors, concluding agreements that will reinforce the economic progress and stimulation of the economic activity with the involvement of the corporations.

But, one society can't evolve if the human factor is forgotten because that human factor from the general public is the main taxpayer who is maintaining the progress of one society and the voice of the human factor needs to be heard, needs to be discussed and needs to be a priority. A key challenge is for the contracting parties is to undertake responsibility for creating a strategy where there would be a constructive dialogue between the investors and the general public, to actively include the general public and to establish the most appropriate structure of policy which is acceptable for the both sides. The contracting parties need to identify the issues and to strengthen the approach towards the problem in a way that supports the public opinion, which approach is going to value in the same time the public interest and the interest of the investors, in terms of economic growth and high value investment policies.

\section{CONCLUSION}

It is indisputable that the Comprehensive Economic and Trade Agreement between Canada and the European Union has unique form which is distinctive from the others type of agreements, but the original constitution of this Agreement does not always mean that the specific formation- should be interpreted in positive connotation by default. The Agreement embolden the discussions about its disputable nature in relation to the dilemma who is truly protected and privileged in the provisions of CETA, especially taking into consideration when the economic and legal justification of the provisions are in question. The provisions of CETA are not really categorical is the corporate 'confrontation' going to be transparent and unambiguous and who is going to take the economic benefits from the implementation of 
the Investment chapter from CETA in the business practice. Achieving the balance between the corporate interest and the public interest is truly complex and difficult objective for realization, but giving consideration to the fact that CETA is a crucial part in the elaboration and interpretation of future international trade agreements and future international investment agreements of this kind, the same should be indicator how some provisions should not be formulated idealistic in the final version of the Agreement. Before being incorporated in the agreements, the implementation of the provisions in business practice should be analyzed in detail by the potential contracting parties, so they will not allow the possible creation of legal discrepancy between the hard copy contractual provisions and the contractual provisions in business practice. Indeed, that is the solution how the provisions of CETA will achieve the balance between the rights and obligations of the investors by strengthening and reinforcing their corporate responsibility and liability. Extremely important for fostering the economic growth and economic progress in a society is the attracting and stimulating the expansion of investments, this is actually the purpose of the international trade agreements that makes the concluding of CETA clearly justified. But, the contracting parties should always pay attention to the possible abuse of power that is given to the investors, to be mindful that the desire for profit maximization can be beyond doubt dangerous and the ability of the states to regulate the public interest by raising the level of protection of the investment standards still leave the opportunity for maltreatment of those standards. Appreciating the analysis above, my conclusion is that CETA will achieve its original objective presented by the contracting parties, when the economic and legal interest will be justified without being at the charge on the public interest. 


\section{REFERENCES}

1. Alvesson, Mats. 2002. Postmodernism and Social Research. Buckingham: Open University Press.

2. Alliance Rights for People, Rules for Corporations - Stop ISDS. (Last accessed on May $25,2020)$ (https://stopisds.org/ceta-its-not-too-late-to-stop-it/)

3. Analysis commissioned by Greenpeace, produced by Ciaran Cross, International Centre for Trade Union Rights (ICTUR). Investor protection in CETA: Gold standard or missed opportunity? Brussels, October 2016. (Assessed April 18, 2020) https://trade-leaks.org/wp-content/uploads/2016/09/ICS-CETA-Report-WEB.pdf

4. Bryman. Alan. 2012. Social Research Methods - fourth edition. United States of America: Oxford University Press.

5. Canadian Centre for Policy Alternatives. Making Sense of CETA - 2nd edition. Berlin/Ottawa: PowerShift, 2016. (Assessed January 29, 2020) https://www.policyalternatives.ca/sites/default/files/uploads/publications/National\%20 Office/2016/09/Making Sense of CETA 2016.pdf

6. Canadian Government and the European Commission. Comprehensive Economic and Trade Agreement (CETA) between Canada, of the one part and the European Union (and its member states. Brussels: 2016. (Assessed March 19, 2020) http://trade.ec.europa.eu/doclib/docs/2016/february/tradoc_154329.pdf

7. Corporate Europe Observatory. The great CETA swindle. Quebec: Centre for Research on Globalization, 2016. (Assessed April 4, 2020) https://corporateeurope.org/sites/default/files/attachments/great-ceta-swindle.pdf

8. European Commission. The benefits of CETA (The Comprehensive Economic and Trade Agreement (CETA) between the EU and Canada. Luxembourg: Publications Office of the European Union, Imprimerie Centrale, 2016. (Assessed January 22, 2020) https://trade.ec.europa.eu/doclib/docs/2016/july/tradoc 154775.pdf

9. European Commission. Guide to the Comprehensive Economic and Trade Agreement (CETA). Luxembourg: Publications Office of the European Union, 2017. (Assessed February 19, 2020) https://trade.ec.europa.eu/doclib/docs/2017/september/tradoc 156062.pdf

10. European Commission. Investment provisions in the EU-Canada free trade agreement (CETA). February, 2016. (Assessed March 12, 2020) https://trade.ec.europa.eu/doclib/docs/2013/november/tradoc_151918.pdf

11. Gray, Paul S., John B. Williamson, David A. Karp and John R. Dalphin. 2007. The Research Imagination: An Introduction to Qualitative and Quantitative. United States of America, New York: Cambridge University Press.

12. House of Commons Canada. Negotiations toward a Comprehensive Economic and Trade Agreement (CETA) between Canada and the European Union. Ottawa: Published 
under the authority of the Speaker of the House of Commons, March 2012. (Assessed April 9, 2020)

https://www.ourcommons.ca/Content/Committee/411/CIIT/Reports/RP5431905/CIITrp 01/ciitrp01-e.pdf

13. Neuman, W. Lawrence. 2014. Social Research Methods: Qualitative and Quantitative Approaches, Seventh Edition. Edinburgh: Pearson Education Limited.

14. Official Journal of the European Union. Joint Interpretative Instrument on the Comprehensive Economic and Trade Agreement (CETA) between Canada and the European Union and its Member States. Brussels: 14 January 2017. (Assessed January 6, 2020) http://data.consilium.europa.eu/doc/document/ST-13541-2016-INIT/en/pdf

15. Office of Parliamentary Budget Officer (Canada). The Canada - EU Comprehensive Economic and Trade Agreement - A Prospective Analysis. Canada, 2 May 2017. (Assessed March 15, 2020) https://www.pbodpb.gc.ca/web/default/files/Documents/Reports/2017/CETA/CETA_EN.pdf

16. Scrivener, Alex. "CETA - It's not too late to stop it" in Rights for People, Rules for Corporations - STOP ISDS. (Last edited 16 July 2019) (https://stopisds.org/ceta-its-not-too-late-to-stop-it/)

17. Tracy, Sarah J. 2019. Qualitative Research Methods: Collecting Evidence, Crafting Analysis, Communicating Impact, 2nd Edition. United States: Wiley-Blackwell.

18. Yin, Robert K. 2015. Qualitative Research from Start to Finish, Second Edition. New York: The Guilford Press. 